University of Nebraska - Lincoln

DigitalCommons@University of Nebraska - Lincoln

USDA National Wildlife Research Center - Staff Publications
U.S. Department of Agriculture: Animal and Plant Health Inspection Service

2013

\title{
Rabies, Canine Distemper, and Canine Parvovirus Exposure in Large Carnivore Communities from Two Zambian Ecosystems
}

Are R. Berentsen

U.S. Department of Agriculture

Mike R. Dunbar

U.S. Department of Agriculture

Matthew S. Becker

Montana State University

Jassiel M'soka

Montana State University

Egil Droge

Zambian Carnivore Programme

See next page for additional authors

Follow this and additional works at: https://digitalcommons.unl.edu/icwdm_usdanwrc

Part of the Life Sciences Commons

Berentsen, Are R.; Dunbar, Mike R.; Becker, Matthew S.; M'soka, Jassiel; Droge, Egil; Sakuya, Nicholas M.; Matandiko, Wigganson; McRobb, Rachel; and Hanlon, Cathleen A., "Rabies, Canine Distemper, and Canine Parvovirus Exposure in Large Carnivore Communities from Two Zambian Ecosystems" (2013). USDA National Wildlife Research Center - Staff Publications. 1448.

https://digitalcommons.unl.edu/icwdm_usdanwrc/1448

This Article is brought to you for free and open access by the U.S. Department of Agriculture: Animal and Plant Health Inspection Service at DigitalCommons@University of Nebraska - Lincoln. It has been accepted for inclusion in USDA National Wildlife Research Center - Staff Publications by an authorized administrator of DigitalCommons@University of Nebraska - Lincoln. 


\section{Authors}

Are R. Berentsen, Mike R. Dunbar, Matthew S. Becker, Jassiel M'soka, Egil Droge, Nicholas M. Sakuya, Wigganson Matandiko, Rachel McRobb, and Cathleen A. Hanlon 


\title{
Rabies, Canine Distemper, and Canine Parvovirus Exposure in Large Carnivore Communities from Two Zambian Ecosystems
}

\author{
Are R. Berentsen,, Mike R. Dunbar,,* Matthew S. Becker,, ${ }^{2,3}$ Jassiel M'soka, ${ }^{2-4}$ Egil Droge, ${ }^{2}$ \\ Nicholas M. Sakuya, ${ }^{5}$ Wigganson Matandiko, ${ }^{2-4}$ Rachel McRobb, ${ }^{6}$ and Cathleen A. Hanlon ${ }^{7}$
}

\begin{abstract}
Disease transmission within and among wild and domestic carnivores can have significant impacts on populations, particularly for threatened and endangered species. We used serology to evaluate potential exposure to rabies virus, canine distemper virus (CDV), and canine parvovirus (CPV) for populations of African lions (Panthera leo), African wild dogs (Lycaon pictus), and spotted hyenas (Crocuta crocuta) in Zambia's South Luangwa National Park (SLNP) and Liuwa Plain National Park (LPNP) as well as community lands bordering these areas. In addition, domestic dogs in the study region were evaluated for exposure to CDV and rabies. We provide the first comprehensive disease exposure data for these species in these ecosystems. Twenty-one lions, 20 hyenas, 13 wild dogs, and 38 domestic dogs were sampled across both regions from 2009 to 2011. Laboratory results show $10.5 \%$ of domestic dogs, $5.0 \%$ of hyenas, and $7.7 \%$ of wild dogs sampled were positive for CDV exposure. All lions were negative. Exposure to CPV was 10.0\% and 4.8\% for hyenas and lions, respectively. All wild dogs were negative, and domestic dogs were not tested due to insufficient serum samples. All species sampled were negative for rabies virus neutralizing antibodies except lions. Forty percent of lions tested positive for rabies virus neutralizing antibodies. Because these lions appeared clinically healthy, this finding is consistent with seroconversion following exposure to rabies antigen. To our knowledge, this finding represents the first ever documentation of rabies virus neutralizing antibodies consistent with rabies exposure that did not lead to clinical disease in free-ranging African lions from this region. With ever-increasing human pressure on these ecosystems, understanding disease transmission dynamics is essential for proper management and conservation of these carnivore species.
\end{abstract}

Key Words: Canine distemper virus—Canine parvovirus-Carnivores—Rabies—Zambia.

\section{Introduction}

$\mathbf{V}$ CTOR-BORNE AND ZOONOTIC DISEASES are an emerging issue worldwide and can have severe socioeconomic consequences (Slingenbergh et al. 2004, Cascio et al. 2011). Diseases such as bovine tuberculosis can affect livestock, wildlife, and human health (Etter et al. 2006), and rabies is responsible for tens of thousands of human deaths globally each year (Knobel et al. 2005). Other pathogens have resulted in disease outbreaks in threatened or endangered wildlife species (Thorne and Williams 1988, Roelke-Parker et al. 1996). Effective management and conservation of wildlife depends in part upon knowledge of diseases that may adversely impact populations through morbidity or mortality. This is particularly important with respect to threatened or endangered species where losses of a few individuals can be

\footnotetext{
${ }^{1}$ U.S. Department of Agriculture, Wildlife Services, National Wildlife Research Center, Fort Collins, Colorado.

${ }^{2}$ Zambian Carnivore Programme, Mfuwe, Zambia.

${ }^{3}$ Department of Ecology, Montana State University, Bozeman, Montana.

${ }^{4}$ Zambia Wildlife Authority, Chilanga, Zambia.

${ }^{5}$ Department of Veterinary and Livestock Development, Kalabo, Zambia.

${ }^{6}$ South Luangwa Conservation Society, Mfuwe, Zambia.

${ }^{7}$ Kansas State University Rabies Laboratory, Manhattan, Kansas.

*Present address: 983 Hwy 93N, Carmen, Idaho.
} 
catastrophic for the population (Murray et al. 1999). Although some diseases result in chronic, subclinical infection (e.g., feline immunodeficiency virus, Packer et al. 1999), canine distemper virus (CDV) can be fatal in some cases (Deem et al. 2000) and rabies is virtually always fatal (Centers for Disease Control and Prevention 2008, Gilbert et al. 2012). Still other diseases, such as canine parvovirus (CPV), may result in mortality primarily among young animals, but surviving animals may exhibit antibody titers as evidence of exposure (Mech and Goyal 1995, Mech et al. 2008).

Rabies and CDV have each been documented in a variety of African carnivore populations, including African wild dogs (Lycaon pictus) (Gascoyne et al. 1993, Kat et al. 1996, Creel and Creel 2002, Van de Bildt et al. 2002, Goller et al. 2007), African lions (Panthera leo) (Bwangamoi et al. 1990, Roelke-Parker et al. 1996, Driciru et al. 2006, Woodroffe, et al. 2007), spotted hyenas (Crocuta crocuta) (Harrison et al. 2004), Ethiopian wolves (Canis simensis) (Sillero-Zubiri et al. 1996, Laurenson et al. 1998), bat-eared foxes (Otocyon megalotis) (Thomson and Meredith 1993), and jackals (C. adustus and C. mesomelas) (Bingham et al. 1999). Canine parvovirus has not been studied as intensively, but has been implicated in high levels of pup mortality in wolves (C. lupus) (Johnson et al. 1994, Mech and Goyal 1995) and may have impacts on African wild dog recruitment in some areas (Creel et al. 1997, Creel and Creel 1998). Furthermore, Harrison et al. (2004) reported a prevalence of CPV exposure of up to $100 \%$ in spotted hyenas for some areas.

In many cases, domestic dogs (C. familiaris) have been implicated as the reservoir for a variety of diseases (Gascoyne et al. 1993, Alexander and Appel 1994, Laurenson et al. 1998, Bingham et al. 1999, Cleaveland et al. 2000, Harrison et al. 2004). Domestic dogs have increased in abundance and distribution throughout Africa (Perry 1995), and vaccination programs are scarce, particularly in rural areas. This has implications for disease transmission as domestic dogs from communities surrounding protected wildlife areas are typically free roaming and may wander several kilometers into national parks (Butler et al. 2004) increasing the risks of coming into contact with susceptible wildlife. Thus, the risk of transmission of diseases such as CDV, CPV, and rabies (Lembo et al. 2007) from domestic dogs to wild carnivores may increase.

The South Luangwa National Park (SLNP) and Liuwa Plain National Park (LPNP) systems provide good comparative systems for disease studies as they differ in key environmental, biological, and anthropogenic variables. SLNP is Zambia's premiere wildlife tourism destination and has the country's largest population of lions and second-largest population of African wild dogs (Becker et al. 2013a, Becker et al. 2013b). Livestock production is minimal due to tsetse flyborne disease and communities are confined to the Game Management Areas (GMAs) surrounding SLNP. GMAs are community lands typically adjacent to protected areas that are intended to serve as buffer zones through sustainable utilization of wildlife through hunting and other activities (Bandyopadhyay and Tembo 2010). In contrast, LPNP is a recovering ecosystem nearly decimated from intensive longterm poaching during the Angolan civil war (1975-2002). While rapidly recovering, LPNP has no functional lion population, but does have recovering populations of wild dogs and cheetahs (Acinonyx jubatus) and a high density of spotted hyenas. LPNP also contains human communities (which include domestic dogs) and livestock within the park boundaries. Although SLNP has a history of disease outbreaks that potentially affect carnivores (i.e., anthrax, Bacillus anthracis; Turnbull et al. 1991), disease dynamics in LPNP are not well described. For both park systems, the existence and extent of carnivore diseases is poorly understood.

Our objective was to perform a serosurvey of disease exposure in Zambian wild carnivores and domestic dogs in communities residing in and around these protected areas. This information will establish baseline data on disease exposure in carnivores and the potential role domestic dogs may play in disease transmission to wild carnivores in Zambia.

\section{Materials and Methods}

\section{Study sites}

The SLNP and the bordering Lupande GMA collectively cover approximately $13,775 \mathrm{~km}^{2}$ (Fig. 1). The area is a mosaic of edaphic grassland, deciduous riparian forest, mopane (Colophospermum mopane) woodland and scrub woodland, miombo woodland, dry deciduous forest, and undifferentiated woodland (Astle et al. 1969, White 1983, Astle 1988). The Luangwa River forms the eastern border for most of the park. Due to limited road networks and seasonal inaccessibility of the study area, sample collection was performed primarily in an approximately $3000-\mathrm{km}^{2}$ area of east-central South Luangwa (Fig. 1) during concurrent studies of lions and wild dogs, as well as during immobilization and treatment of carnivores found entangled in poachers' snares (Becker et al. 2013b).

The LPNP is $3660 \mathrm{~km}^{2}$ of grasslands, wooded islands, and floodplains in Zambia's Western province (Fig. 1). It is home to the second largest wildebeest (Connochaetes taurinus) migration on the continent, behind East Africa, and with no functional lion population, LPNP is a spotted hyena-dominated system. Now under the management of African Parks Network, game species in LPNP are increasing, along with populations of lions, cheetahs, and African wild dogs. However, with carnivore populations still relatively low, disease outbreaks could reverse their current increasing population trend.

\section{Sample collection and handling}

Wild carnivores were chemically immobilized opportunistically as either part of radio-collaring efforts for intensive studies or to remove wire poaching snares in which animals had become entrapped. All carnivores sampled during this study were regularly relocated in the study areas throughout the year (see Becker et al. 2013a and Becker et al. 2013b for a description of methods).

Drugs for immobilization consisted of a mixture of Tileatmine/Zolazepam (Zoletil $^{\circledR}$, Virbac, South Africa) and Medetomidine (Domitor ${ }^{\circledR}$, Kyron Laboratories/Pfizer Animal Health, South Africa), and were reversed with Atipamezole (Antisedan ${ }^{\circledR}$, Novartis Animal Health, South Africa) (Kock et al. 2006). During immobilization, the animals' eyes were protected with a cloth covering the face, vital signs were monitored, and dart injection sites were treated with topical antibiotics. Blood samples were collected via venipuncture of the jugular, cephalic, or saphenous vein and transferred to serum separator tubes. Domestic dogs were physically 


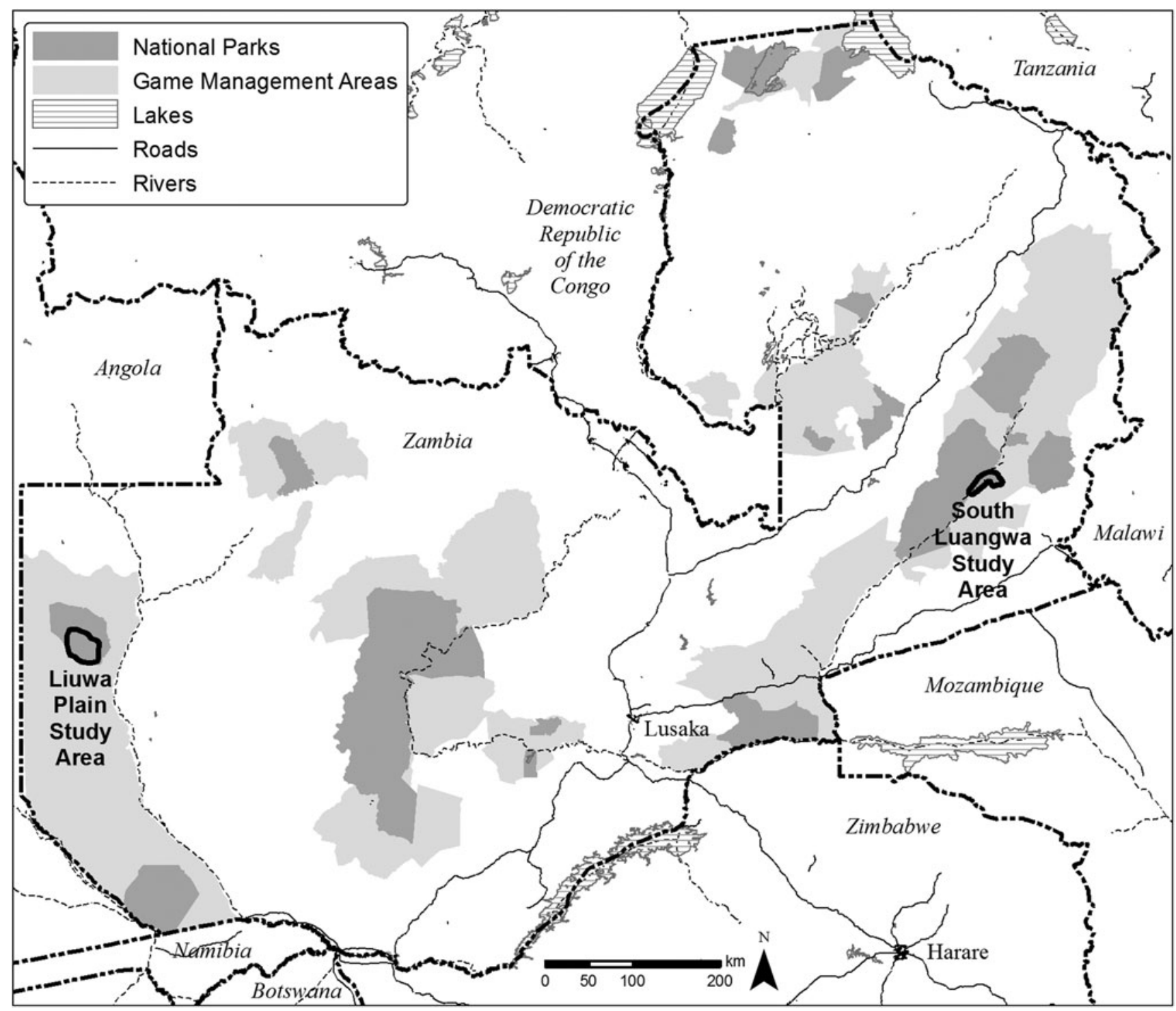

FIG. 1. Locations of South Luangwa National Park and Liuwa Plain National Park, Zambia.

restrained and samples were collected via venipuncture of the cephalic vein. Domestic dogs in this study had not been vaccinated for CDV, CPV, or rabies. All immobilization procedures followed animal welfare standards and protocols required by the Zambia Department of Veterinary and Livestock Development and the Zambia Wildlife Authority. All procedures were approved by the National Wildlife Research Center's Institutional Animal Care and Use Committee under Protocol QA-1725.

Samples were stored in an insulated cooler with frozen gel packs during transport to the laboratory, where serum was separated via centrifugation within $24 \mathrm{~h}$ of collection. Serum was extracted and stored in cryovials at $-20^{\circ} \mathrm{C}$ until shipped frozen overnight to the US Department of Agriculture (USDA), National Wildlife Research Center in Fort Collins, Colorado. Samples thawed during international transport but were refrozen at $-80^{\circ} \mathrm{C}$ upon arrival in Colorado. Approximately 30 days prior to analysis samples were allowed to thaw at room temperature, transferred via disposable pipette to a $5.0-\mathrm{mL}$ tube, and refrigerated.

\section{Laboratory analysis}

Analyses for detecting CDV and CPV antibodies were performed by the Animal Health Diagnostic Center at Cornell University, Ithaca, NY. Analysis for CDV was carried out using a serum neutralization test with the Onderstepoort virus strain (Appel and Robson 1973). Study subjects whose serum samples showed evidence of virus neutralization at dilution levels $\geq 1: 8$ were considered likely exposed to CDV (Woodroffe et al. 2012). Analysis for CPV was performed using a hemagglutination inhibition test (Carmichael et al. 1980). Serum samples with detectable virus neutralization antibodies at dilution levels $\geq 1: 20$ were considered seropositive for CPV (Woodroffe et al. 2012).

Rabies virus neutralizing antibody analyses were performed at the Kansas State University Rabies Laboratory, Manhattan, Kansas, using a rapid fluorescent focus inhibition test (RFFIT) with reported end points. At this Rabies Laboratory, a titer level of $\geq 0.10$ International Units (IU) $/ \mathrm{mL}$ is the equivalent IU/mL level of "complete neutralization at 
Table 1. Numbers of Lions, Hyenas, Wild Dogs, and Domestic Dogs Found Exposed to CDV, CPV, and Rabies in South Luangwa National Park, Zambia

\begin{tabular}{|c|c|c|c|c|c|c|c|c|c|}
\hline & \multicolumn{3}{|c|}{$C D V$} & \multicolumn{3}{|c|}{$C P V$} & \multicolumn{3}{|c|}{ Rabies virus neutralizing antibody } \\
\hline & Likely exposed & Negative & $\mathrm{n}$ & Likely exposed & Negative & $\mathrm{n}$ & Positive & Negative & $\mathrm{n}$ \\
\hline Panthera leo & 0 & 20 & 20 & 1 & 19 & 20 & 7 & 12 & 19 \\
\hline Crocuta crocuta & 1 & 9 & 10 & 1 & 9 & 10 & 0 & 10 & 10 \\
\hline Lycaon pictus & 0 & 9 & 9 & 0 & 9 & 9 & 0 & 6 & 6 \\
\hline Canis familiaris & 0 & 10 & 10 & $\mathrm{~N} / \mathrm{A}$ & $\mathrm{N} / \mathrm{A}$ & $\mathrm{N} / \mathrm{A}$ & 0 & 8 & 8 \\
\hline
\end{tabular}

$\mathrm{CDV}$, canine distemper virus; $\mathrm{CPV}$, canine parvovirus; N/A, not applicable.

1:5." This level is considered seropositive according to Human Rabies Prevention-Recommendations of the Advisory Committee on Immunization Practices (Centers for Disease Control and Prevention 2008). A level of $0.1 \mathrm{IU} / \mathrm{mL}$ is a low level and around the limit of quantitation, but it is considered seropositive for humans and some other species. The method has not been validated for the wildlife species in this study, so this level was interpreted conservatively as indeterminate. Therefore, samples at $0.2 \mathrm{IU} / \mathrm{mL}$ and above were classified as seropositive.

\section{Results}

\section{South Luangwa National Park}

In SLNP, sufficient serum for CDV analysis was obtained from 10 domestic dogs, 20 lions, 10 spotted hyenas, and 9 wild dogs. One hyena $(10 \%)$ was seropositive, with all other samples negative. Sufficient serum samples were obtained from 20 lions, 10 spotted hyenas, and 9 wild dogs for CPV testing. One lion (5\%) and 1 hyena (10\%) were seropositive. No domestic dogs were tested for CPV exposure due to insufficient serum sample volumes. Rabies neutralizing antibody titer testing was performed on samples from 19 lions, 10 hyenas, 6 wild dogs, and 8 domestic dogs (Table 1). Seven lions (37\%) had antibody titers $\geq 0.2 \mathrm{IU} / \mathrm{mL}$ and were considered seropositive for rabies exposure (Table 1).

\section{Liuwa Plain National Park}

At LPNP, sufficient serum samples for CDV analysis was obtained from 28 domestic dogs, 1 lion, 11 spotted hyenas, and 3 wild dogs. Four domestic dogs (14\%) were seropositive. Sufficient serum samples for CPV testing were obtained from 1 lion, 10 spotted hyenas, and 3 wild dogs (Table 2). One hyena $(10 \%)$ was seropositive. Domestic dogs were not tested for CPV exposure due to insufficient serum sample volumes. Serum samples from 1 lion, 20 hyenas, 3 wild dogs, and 22 domestic dogs were tested for rabies virus neutralizing antibodies. One domestic dog sample was toxic to cells during rabies testing, likely a result of hemolysis, and no titer result was obtained. The single lion from LPNP had a rabies antibody titer of $\geq 0.7 \mathrm{IU} / \mathrm{mL}$ and was considered positive for exposure to rabies antigen (Table 2).

\section{Discussion}

We provide the first data on exposure for three of the most significant large carnivore diseases in Africa for two of Zambia's most important ecosystems. This research provides a baseline upon which more intensive research can be conducted to elucidate disease transmission dynamics and potential disease risks and impacts on these populations. Of primary interest is the high percentage of lions (40\% overall; 8/20) that have rabies virus neutralizing antibodies, most likely indicative of exposure to rabies antigen. To our knowledge, this is the first indication of rabies antigen exposure and seroconversion in free-ranging African lions. However, such dynamics have been documented in other taxa. For example, studies by East et al. (2001) in Tanzania found rabies virus neutralizing antibodies in spotted hyenas, but no apparent clinical infection. As a result, East et al. (2001) concluded that spotted hyenas likely did not contribute to the natural transmission patterns of rabies in the locality affecting wild dogs that died of rabies in the Serengeti ecosystem in the 1990s. Gascoyne et al. (1993) found wild dogs with rabies virus neutralizing antibody titers in Tanzania that showed no clinical signs of disease, although it is unknown whether the titers were related to previous sublethal exposure to rabies virus. Ramey et al. (2008) documented rabies neutralizing antibody titers in unvaccinated raccoons (Procyon lotor) prior to distribution of oral rabies vaccine baits in Ohio, but the cutoff level to classify "positive samples" was notably low (0.05 IU/mL). Lastly, Deem et al. (2004) documented seropositivity compatible with nonfatal rabies exposure in an Oncilla (Leopardus tigris) in Bolivia.

Table 2. Numbers of Lions, Hyenas, Wild Dogs, and Domestic Dogs Seropositive for CDV, CPV, and Rabies Virus Neutralizing Antibodies in Liuwa Plain National Park, Zambia

\begin{tabular}{|c|c|c|c|c|c|c|c|c|c|}
\hline & \multicolumn{3}{|c|}{$C D V$} & \multicolumn{3}{|c|}{$C P V$} & \multicolumn{3}{|c|}{ Rabies virus neutralizing antibodies } \\
\hline & Likely Exposed & Negative & $\mathrm{n}$ & Likely Exposed & Negative & $\mathrm{n}$ & Positive & Negative & $\mathrm{n}$ \\
\hline Panthera leo & 0 & 1 & 1 & 0 & 0 & 1 & 1 & 0 & 1 \\
\hline Crocuta crocuta & 0 & 10 & 10 & 1 & 9 & 10 & 0 & 0 & 10 \\
\hline Lycaon pictus & 1 & 2 & 3 & 0 & 3 & 3 & 0 & 3 & 3 \\
\hline Canis familiaris & 4 & 24 & 28 & $\mathrm{~N} / \mathrm{A}$ & $\mathrm{N} / \mathrm{A}$ & $\mathrm{N} / \mathrm{A}$ & 0 & 22 & 22 \\
\hline
\end{tabular}

$\mathrm{CDV}$, canine distemper virus; $\mathrm{CPV}$, canine parvovirus; N/A, not applicable. 
Table 3. Rabies Virus Neutralizing Antibody Titers For Lions Sampled in South Luangwa National Park and LiUwa Plain National Park, Zambia

\begin{tabular}{lccl}
\hline Location & $\begin{array}{c}\text { Number } \\
\text { of animals }\end{array}$ & $\begin{array}{c}\text { RVNA level } \\
(I U / m L)\end{array}$ & Interpretation \\
\hline SLNP & 1 & 1.8 & Positive \\
& 2 & 0.9 & Positive \\
& 1 & 0.5 & Positive \\
Subtotal & 3 & 0.2 & Positive \\
LPNP & 6 & 0.1 & Inconclusive \\
Overall & 19 & $<0.1$ & Negative \\
& 1 & Prevalence & $7 / 19(37 \%)$ \\
\hline
\end{tabular}

RVNA, Rabies virus neutralizing antibodies; SLNP, South Luangwa National Park; LPNP, Liuwa Plain National Park.

The World Health Organization considers a rabies virus neutralizing antibody titer level of $\geq 0.5 \mathrm{IU} / \mathrm{ml}$ to be adequate evidence of rabies vaccination in humans (World Health Organization 2005). Titer levels for lions in this study ranged from $0.2 \mathrm{IU} / \mathrm{mL}$ to $1.8 \mathrm{IU} / \mathrm{mL}$, with $5 / 8(63 \%)$ positive lions showing titers $\geq 0.5 \mathrm{IU} / \mathrm{ml}$ (Table 3 ). With such results, it appears that these lions are primed against rabies and may be protected against rabies infection. However, protective titers against severe rabies challenge have not been established for many species, including African lions. As with many diseases, documenting antibody titers to rabies does not imply active infection, merely pathogen exposure. In the case of rabies, such exposure may not be fatal, but rather may result in immunization, especially if the route of exposure is not parentral via bite but by some less invasive route such as oral consumption of rabies-positive tissue. Given the widespread prevalence of exposure in the SLNP population and the fact that none of the lions in this study showed clinical or behavioral signs of rabies or any signs of compromised health, and all remain alive and breeding several years after sampling, they may have become exposed through ingestion of rabies-infected prey species as is thought to have occurred in Namibia (Mansfield et al. 2006). Nor has it been determined whether they are capable of transmitting the virus. Further research into exposure, transmissibility, virus isolation, and sequencing from this species in these localities is warranted to identify rabies virus strains, the virulence of the strains, and their potential source, similar to the study communicated by Lembo et al (2007).

It is possible that the titers observed in lion serum samples were the result of exposure to other lyssaviruses. Other studies have found rabies virus neutralizing antibodies without clinical disease (Turmelle et al. 2010, Gilbert et al. 2012), although these cases were the result of exposure to nonterrestrial (i.e., bat variant) rabies virus. If other lyssaviruses are circulating in the area and the lions become exposed to them, the serum samples may exhibit higher titers if these other viruses were used in the neutralization test rather than the challenge virus standard [rabies virus (RABV), genotype 1]. However, the epizootiology of rabies-related viruses is much lower and sporadic than canine rabies and other wildlife terrestrial rabies cycles in the area. On the basis of epizootiologic characteristics, the probability of the observed reactivity being invoked by rabies-related variants associated with bats (e.g., Duvenhage virus, Lagos bat virus,
Shimoni virus) or an unidentified reservoir (such as Mokola virus) is likely much lower than the probability of its source being from canine or other terrestrial rabies virus variants. Röttcher and Sawchuk (1978) found jackals were the dominant wildlife reservoir for rabies in Zambia. Bellan et al. (2012) documented apparent asymptomatic rabies infections in jackals in Namibia and suggested the strain was closely related to that found in domestic dogs and other terrestrial wildlife. Thus, we believe lions would have less probability of contact with a lyssavirus-infected sick bat than with a rabies virus-infected terrestrial carnivore.

East et al. (2001) found that spotted hyenas in Tanzania were infected with a rabies virus strain unrelated to those found in rabies reservoirs in that region and exposure did not produce a long-term persistence of rabies virus neutralizing antibodies. They suggest that the hyenas in their study site may have co-evolved with a less virulent strain of rabies that was maintained within the hyena population through bouts of intraspecific aggression. It is uncertain how such exposure amongst lions occurred in the SLNP study area; however, positive individuals shared relatively contiguous ranges. These individuals and/or their cohorts in the respective prides and coalitions used the GMAs to varying degrees. Villages in these areas had populations of domestic dogs that primarily resided in the communities, and predation by lions and hyenas was not uncommon. Thus, exposure within and among prides and coalitions was possible. However, given the lack of apparent exposure for sympatric carnivore species and domestic dogs, such a dynamic is unlikely to have caused the observed titer levels. Despite this being previously undocumented, the prevalence of such exposure across Zambia's eastern and westernmost lion populations likely indicates that such dynamics are not unusual in the region, but further investigation is needed.

Prevalence of CDV and CPV exposure in all carnivores (except domestic dogs, because they were not tested for CPV) in this study was lower than those described for other regions in Sub-Saharan Africa. The number of domestic dog samples in this study was unfortunately limited by a lower than expected domestic dog population, particularly at SLNP. The reasons for this are unknown, but may be related to periodic outbreaks of African sleeping sickness (trypanosomiasis) in the region (Z.C.P., direct observation). Despite the relatively small overall sample size, $14 \%$ of domestic dogs in LPNP were seropositive for CDV exposure. Dricuru et al. (2006) reported CDV and CPV prevalence in lions in Uganda of 79\% and $36 \%$, respectively. Creel et al. (1997) documented 59\% and 68\% exposure to CDV and CPV, respectively, in wild dogs in Tanzania. Harrison et al. (2004) documented CPV in up to $81 \%$ of spotted hyenas and suggested that close proximity to human habitation played a role. The fact that we observed lower exposure rates to CDV than those in East Africa is not too surprising, given a history of periodic distemper outbreaks in that region (Alexander et al. 1995, Roelke-Parker et al. 1996, Goller et al. 2010). Differences in domestic dog densities among regions may also be a contributing factor, although a wildlife reservoir cannot be ruled out (Woodroffe et al. 2012).

The potential impact of rabies, CDV, and CPV on threatened and endangered carnivore populations cannot be understated, nor can the potential role of domestic dogs in disease transmission. Increasing human activity and settlement in and around protected areas may result in increasing 
contact with domestic dogs and higher risks of disease transmission. Woodroffe and Donnelly (2011) concluded that rabies transmission in Kenya between domestic dogs and wild dogs was unlikely because wild dogs avoided human settlements. However, in LPNP wild dogs have denned within $0.5-2 \mathrm{~km}$ of villages, and wild dogs have been documented $<1 \mathrm{~km}$ of villages in SLNP (Z.C.P., direct observation). Vaccination of domestic dogs from communities in and around protected areas may be a viable option for controlling diseases exposure. Research into this topic suggests the success of vaccination may be dependent upon several factors (not the least of which are expense and logistical challenges), including population density of the target species and the virulence of the pathogen for which vaccination is being considered (Prager et al. 2011). In domestic dogs, rabies is likely to persist only in high-density populations owing to the lengthy incubation time and relatively short period of transmissibility of the virus (Cleaveland and Dye 1995; Lembo et al. 2008). Vaccination against pathogens, such as rabies, that have up to $100 \%$ mortality could be beneficial, yet postexposure host immunity to diseases that have relatively low rates of mortality, such as CDV, may render vaccination unnecessary (Prager et al. 2011). Whether vaccination of domestic dogs is an effective means to decrease disease exposure to free-ranging carnivores is a topic that requires further study.

\section{Conclusions}

On the basis of this serosurvey, there appears to be a relatively low prevalence of exposure to CDV in lions, hyenas, wild dogs, and domestic dogs and CPV in lions, hyenas, and wild dogs in two Zambian ecosystems. This is the first documentation of rabies antibody-positive findings in lions. This finding most likely indicates natural exposure to rabies antigen, either through exposure to low, subinfectious doses of live virus, exposure to virus by a route with a low likelihood of infection such as orally (rather than the natural parenteral route through a bite), and/or exposure to virus that has been partially or fully inactivated by heat, desiccation, or tissue autolysis. The mechanisms behind infection, whether virus transmission is possible, and the role of domestic dogs in disease transmission in this region remain an area in need of further research.

\section{Acknowledgments}

The authors thank the Zambia Wildlife Authority and Department of Veterinary and Livestock Development for their permission and collaboration in this research. Funding for SLNP and LPNP work was provided from Worldwide Fund for Nature-Netherlands, African Parks Network, Painted Dog Conservation Inc., and the Royal Society for Prevention of Cruelty to Animals. We thank P. Bouley, C. Chirwa, C. Harrison, J. Lemon, T. Mweetwa, C. Mulipukwa, F. Otten, and E. Rosenblatt for field assistance.

\section{Author Disclosure Statement}

No conflicts of interest exist.

\section{References}

Alexander KA, Appel MJG. 1994. African wild dogs (Lycaon pictus) endangered by a canine distemper epizootic among domestic dogs near the Masai Mara National Reserve, Kenya. J Wildlife Dis 1994; 30:481-485.

Alexander KA, Kat PW, Frank LG, Holekamp KE, et al. Evidence of canine distemper virus infection among free-ranging hyenas (Crocuta crocuta) in the Masai Mara, Kenya. J Zoo Wildlife Med 1995; 26:201-206.

Appel MJG, Robson DS. A microneutralization test for canine distemper virus. Am J Vet Res 1973; 34:1459-1463.

Astle WL. Republic of Zambia, South Luangwa National Park Map, Landscape and Vegetation. Oxford: Lovell Johns, 1988.

Astle WL, Webster R, Lawrance CJ. Land classification for management planning in the Luangwa valley of Zambia. J Appl Ecol 1969; 6:143-169.

Bandyopadhyah S, Tembo G. Household consumption and natural resource management around national parks in Zambia. J Nat Resour Policy Res 2010; 2:39-55.

Becker MS, Watson F, Droge E, Leigh K. et al. Estimating past and future male loss in three Zambian lion populations. J Wildlife Manage 2013a; 77:128-142.

Becker MS, McRobb R, Watson F, Droge E, et al. Evaluating wire-snare poaching trends and the impacts of by-catch on elephants and large carnivores. Biol Conserv 2013b; 158:26-36.

Bellan SE, Cizauskas CA, Miyen J, Ebersohn K, et al. Blackbacked jackal exposure to rabies virus, canine distemper virus, and Bacillus anthracis, in Etosha National Park, Namibia. J Wildlife Dis 2012; 48:371-381.

Bingham J, Foggin CM, Wandeler AI, Hill FWG. The epidemiology of rabies in Zimbabwe 2: Rabies in jackals (Canis adustus and Canis mesomelas). Onderstepoort J Vet 1999; 66:11-23.

Butler JRA, Du Toit JT, Bingham J. Free-ranging domestic dogs (Canis familiaris) as predators and prey in rural Zimbabwe: Threats of competition and disease to large wild carnivores. Biol Conserv 2004; 115:369-378.

Bwangamoi O, Rottcher D, Wekesa L. Rabies, microbesnoitosis and sarcocystis in a lion. Vet Rec 1990; 127:411.

Carmichael LE, Jourber JC, Pollock RV. Hemagglutination by canine parvovirus: Serologic studies and diagnostic applications. Am J Vet Res 1980; 41:784-791.

Cascio A, Bosilkovski M, Rodruguez-Morales AJ, Pappas G. The socio-ecology of zoonotic infections. Clin Microbiol Infec 2011; 17:336-342.

Centers For Disease Control and Prevention: Recommendations of the Advisory Committee on Immunization Practices (ACIP). Morb Mort Weekly Rep 2008; 57:1-36.

Cleaveland S, Dye C. Maintenance of a microparasite infecting several host species: Rabies in the Serengeti. Parasitology 1995; 111:S33-S47.

Cleaveland S, Appel MGJ, Chalmers WSK, Chillingworth C, et al. Serological and demographic evidence for domestic dogs as a source of canine distemper virus infection for Serengeti wildlife. Vet Microbiol 2000; 72:217-227.

Creel S, Creel NM. Six ecological factors that may limit African wild dogs, Lycaon pictus. Anim Conserv 1998; 1:1-9.

Creel S, Creel NM. Infectious Diseases. In: The African Wild Dog: Behavior, Ecology and Conservation. Princeton, NJ: Princeton University Press, 2002:274-287.

Creel S, Creel NM, Munson L, Sanderlin D, et al. Serosurvey for selected viral diseases and demography of African wild dogs in Tanzania. J Wildlife Dis 1997; 33:823-832.

Deem SL, Spelman LH, Yates RA, Montali RJ. Canine distemper in terrestrial carnivores: A review. J Zoo Wildlife Med 2000; 31:441-451.

Deem SL, Davis R, Pacheco LF. Serologic evidence of nonfatal rabies exposure in a free-ranging Oncilla (Leopardus tigris) in 
Cotapata National Park, Bolivia. J Wildlife Dis 2004; 40: 811-815.

Driciru M, Siefert L, Prager KC, Dubovi E, et al. A serosurvey of viral infections in lions (Panthera leo) from Queen Elizabeth National Park, Uganda. J Wildlife Dis 2006; 42:667-671.

East ML, Hofer H, Cox JH, Wulle U, et al. Regular exposure to rabies virus and lack of symptomatic disease in Serengeti spotted hyenas. Proc Natl Acad Sci USA 2001; 98:15026-15031.

Etter E, Donado P, Jori F, Caron A, et al. Risk analysis and bovine tuberculosis, a re-emerging zoonosis. Ann NY Acad Sci 2006; 1081:61-73.

Gascoyne SC, Laurenson MK, Lelo S, Borner M. Rabies in African wild dogs (Lycaon pictus) in the Serengeti region, Tanzania. J Wildlife Dis 1993; 29:396-402.

Gilbert AT, Petersen BW, Recuenco S, Niezgoda, M, et al. Evidence of rabies virus exposure among humans in the Peruvian Amazon. Am J Trop Med Hyg 2012; 87:206-215.

Goller KV, Fyumagwa RD, Nikolin V, East ML, et al. Fatal canine distemper infection in a pack of African wild dogs in the Serengeti ecosystem, Tanzania. Vet Microbiol 2010; 146: 245-252.

Harrison TM, Mazet JK, Holekamp KE, Dubovi E, et al. Antibodies to canine and feline viruses in spotted hyenas (Crocuta crocuta) in the Masai Mara National Reserve. J Wildlife Dis 2004; 40:1-10.

Johnson MR., Boyd DK, Pletscher DH. Serologic investigations of canine parvovirus and canine distemper in relation to wolf (Canis lupus) pup mortalities. J Wildlife Dis 1994; 30:270-273.

Kat PW, Alexander KA, Smith JS, Richardson JD, et al. Rabies among African wild dogs (Lycaon pictus) in the Masai Mara, Kenya. J Vet Diagn Invest 1996; 8:420-426.

Knobel DL, Cleaveland S, Coleman PG, Fèvre EM, et al. Reevaluating the burden of rabies in Africa and Asia. B World Health Organ 2005; 83:360-368.

Kock MD, Meltzer D, Burroughs R. Chemical and physical restraint of wild animals. Greyton, South Africa: IWVS (Africa), Publishers, 2006.

Laurenson K, Sillero-Zubiri C, Thompson H, Shiferaw F, et al. Disease as a threat to endangered species: Ethiopian wolves, domestic dogs and canine pathogens. Anim Conserv 1998; $1: 273-280$.

Lembo T, Haydon DT, Velasco-Villa A, Rupprecht, et al. Molecular epidemiology identifies only a single rabies virus variant circulating in complex carnivore communities of the Serengeti. Proc R Soc B 2007; 274:2123-2130.

Lembo T, Hampson K, Haydon DT, Craft M, et al. Exploring reservoir dynamics: A case study of rabies in the Serengeti ecosystem. J Appl Ecol 2008; 45:1246-1257.

Mansfield K, McElhinney L, Hübschle O, Mettler F, et al. A molecular epidemiological study of rabies epizootics in kudu (Tragelaphus strepsiceros) in Namibia. BMC Veterinary Research 2006; 2:2. doi:10.1186/1746-6148-2-2. Available at http://www .biomedcentral.com/1746-6148/2/2. Last accessed May 27, 2013.

Mech LD, Goyal SM. Effects of canine parvovirus on gray wolves in Minnesota. J Wildlife Manage 1995; 59:565-570.

Mech LD, Goyal SM, Paul WJ, Newton WE. Demographic effects of canine parvovirus on a free-ranging wolf population over 30 years. J Wildlife Disease 2008; 44:824-836.

Murray DL, Kapke CA, Evermann JF, Fuller TK. Infectious disease and the conservation of free-ranging large carnivores. Anim Cons 1999; 2:241-254.
Packer C, Altizer S, Appel M, Brown E, et al. Viruses of the Serengeti: Patterns of infection and mortality in African lions. J Anim Ecol 1999; 68:1161-1178.

Perry BD. Rabies control in the developing world: Can further research help? Vet Rec 1995; 137:521-522.

Prager KC, Woodroffe R, Cameron A, Haydon DT. Vaccination strategies to conserve the endangered African wild dog ( $L y$ caon pictus). Biol Conserv 2011; 144:1940-1948.

Ramey PC, Blackwell BF, Gates RJ, Slemons RD. Oral rabies vaccination of a northern Ohio raccoon population: Relevance of population density and prebait serology. J Wildlife Dis 2008; 44:553-568.

Roelke-Parker ME, Munson L, Packer C, Kock R, et al. A canine distemper epidemic in Serengeti lions (Panthera leo). Nature 1996; 379:441-445.

Röttcher D, Sawchuk AM. Wildlife rabies in Zambia. J Wildlife Dis $1978 ; 14: 513-517$.

Sillero-Zubiri C, King AA, MacDonald DW. Rabies and mortality in Ethiopian wolves (Canis simensis). J Wildlife Dis 1996; 32:80-86.

Slingenbergh J, Gilbert M, de Balgogh K, Wint W. Ecological sources of zoonotic diseases. Rev Sci Tech Off Int Epiz 2004; 23:467-484.

Thomson GR, Meredith CD. Rabies in bat-eared foxes in South Africa. Onderstepoort J Vet 1993; 60:399-403.

Thorne ET, Williams ES. Disease and endangered species: The black-footed ferret as a recent example. Conserv Biol 1988; 2:66-74.

Turmelle AS, Jackson FR, Green D, McCracken GF, et al. Host immunity to repeated rabies virus infection in big brown bats. J Gen Virol 2010; 91:2360-2366

Turnbull PC, Bell RH, Saigawa K, Munyenyembe FE, et al. Anthrax in wildlife in the Luangwa valley, Zambia. Vet Rec 1991; 128:399-403.

Van De Bildt MWG, Kuiken T, Visee AM, Lema S, et al. Distemper outbreak and its effect on African wild dog conservation. Emerg Infec Dis 2002; 8:211-213.

White, F. The Vegetation of Africa: A Descriptive Memoir to Accompany the UNESCO/AETFAT/UNSO Vegetation Map of Africa. Paris: United Nations Educational, Scientific and Cultural Organization, 1983.

Woodroffe R, Donnelly CA. Risk of contact between endangered African wild dogs Lycaon pictus and domestic dogs: Opportunities for pathogen transmission. J Appl Ecol 2011; 48:13451354.

Woodroffe R, Davies-Mostert HJ, Ginsberg J, Graf J, et al. Rates and causes of mortality in endangered African wild dogs $L y$ caon pictus: lessons for management and monitoring. Oryx 2007; 41:215-223.

Woodroffe R, Prager KC, Munson L, Conrad PA, et al. Contact with domestic dogs increases pathogen exposure in endangered African wild dogs (Lycaon pictus). PLoS One 2012; 7:1-9. World Health Organization. WHO Expert Consultation on Rabies, First Report. TRS 931, Geneva, Switzerland: WHO, 2005;121pp.

Address correspondence to: Are R. Berentsen USDA/APHIS/WS/National Wildlife Research Center 4101 LaPorte Avenue Fort Collins, CO, 80521

E-mail: are.r.berentsen@aphis.usda.gov 